\title{
PERILAKU APARATUR SIPIL NEGARA DALAM MEMBERIKAN PELAYANAN PRIMA (EXCELLENT SERVICE) PADA DINAS PENANAMAN MODAL DAN PELAYANAN TERPADU SATU PINTU KOTA KENDARI
}

\author{
${ }^{1}$ Muhammad Amir, ${ }^{2}$ Sitti Hairani Idrus, ${ }^{3}$ Ardot \\ 1,2,3 Fakultas IImu Sosial dan IImu Politik, Universitas Halu Oleo \\ amir.fisipuh@gmail.com, sitihairani@uho.ac.id, ardotpublic@gmail.com \\ Kendari - Indonesia
}

\begin{abstract}
This study aims to determine and describe the behavior of the State Civil Apparatus in providing services and describing the Implementation of Excellent Services at the One-stop Investment and Integrated Services Office of Kendari City. The research method used is descriptive qualitative research, a description of the results of interview observations and documentation studies, so as to be able to describe various matters relating to the Behavior of State Civil Apparatuses in Providing Excellent Service. The results showed that the behavior of the State Civil Apparatus in providing Prime services in terms of the dimensions of receiving, responding, respecting and being responsible for providing services to service users had gone quite well, but the implementation was not optimal because there were still found several employees who had not shown behavior and good treatment to the community. Implementation of excellent service in terms of dimensions of service procedures, service costs, completion time, service products, facilities, infrastructure, competency of service providers as a whole is good.
\end{abstract}

Keywords: Apparatus; Behavior; Excellent Service

\begin{abstract}
Abstrak
Penelitian ini bertujuan untuk Mengetahui dan mendeskripsikan Perilaku Aparatur Sipil Negara dalam memberikan pelayanan serta mendeskripsikan Pelaksanaan Pelayanan Prima (Excellent Service) Pada Dinas Penanaman Modal Dan Pelayanan Terpadu Satu Pintu Kota Kendari . Metode penelitian yang digunakan adalah penelitian kualitatif bersifat deskriptif, uraian dari hasil observasi wawancara dan studi dokumentasi, sehingga mampu mendeskripsikan berbagai hal berkaitan tentang Perilaku Aparatur Sipil Negara dalam Memberikan Pelayanan Prima (Excellent Service). Hasil penelitian menunjukkan bahwa Perilaku Aparatur Sipil Negara dalam memberikan pelayanan Prima di tinjau dari dimensi menerima, merespon, menghargai dan bertanggung jawab dalam memberikan pelayanan terhadap pengguna layanan (masyarakat) sudah berjalan cukup baik, akan tetapi pelaksanaannya belum optimal karena masih ditemukan beberapa pegawai yang belum menunjukan perilaku dan perlakuan yang baik kepada masyarakat. Pelaksanaan pelayanan prima di tinjau dari dimensi prosedur pelayanan, biaya pelayanan, waktu penyelesaian, produk pelayanan, sarana prasana, kompetensi petugas pemberi layanan secara keseluruhan sudah baik.
\end{abstract}

\section{Kata Kunci: Aparatur; Perilaku; Pelayanan Prima}

Open Access at: http://ojs.uho.ac.id/index.php/PUBLICUHO/index

Journal Publicuho is licensed under a Creative Commons Attribution 4.0 International License. 


\section{PENDAHULUAN}

Didalam organisasi sektor publik, Pelayanan publik merupakan segala bentuk pelayanan yang diberikan oleh Pemerintah Pusat / Daerah, BUMN / BUMD dalam rangka pemenuhan kebutuhan masyarakat sesuai dengan Peraturan Perundang-Undangan yang berlaku,untuk itu dalam rangka meningkatkan kualitas pelayanan, maka diperlukan bentuk pelayanan prima, Pelayanan prima atau "Excellence Service" adalah suatu sikap atau cara karyawan dalam melayani pelanggan secara memuaskan (Elthainammy, 1990).

Pelayanan prima adalah bagian penting untuk meningkatkan citra pelayanan, Undang-Undang Nomor 25 tahun 2009 menyatakan bahwa pelayanan prima adalah pelayanan yang cepat, mudah, pasti, murah, dan akuntabel, Pelayanan prima merupakan suatu pelayanan terbaik, melebihi, melampaui, mengungguli pelayanan yang diberikan pihak lain atau dari pada pelayanan waktu yang lalu. Secara sederhana, Dengan kata lain, pelayanan prima merupakan suatu pelayanan yang memenuhi standar kualitas,Pelayanan yang memenuhi standar kualitas adalah suatu pelayanan yang sesuai dengan harapan dan kepuasan pelanggan/masyarakat.

Pada dasarnya pelayanan prima mengandung tiga aspek, yakni (1) kemampuan yang professional, (2) kemampuan yang teguh, (3) sikap yang ikhlas, tulus, senang membantu, menyelesaikan kepentingan, keluhan, memuaskan kebutuhan pelanggan dengan memberikan pelayanan yang terbaik. Pada zaman yang semakin modern ini, Masyarakat sangat membutuhkan pelayanan yang memiliki kualitas, Maka perilaku Pelayanan prima dipandang perlu untuk dimasukkan sebagai salah satu aspek yang penting dalam pelaksanaan kegiatan di instansi publik manapun.

Berdasarkan Peraturan Menteri Pendayagunaan Aparatur Negara No 7 Tahun 2010 Tentang Pedoman Penilaian Kinerja Unit Pelayanan Publik, indikator yang dinilai dalam menilai bahwa pelayanan prima dapat dilihat dari visi, misi, sumber daya dan sarana prasarananya. Seperti halnya pada Dinas Penanaman Modal Dan Pelayanan Terpadu Satu Pintu Kota Kendari sebagai sebuah instansi Organisasi Perangkat Daerah yang memiliki visi : "Terwujudnya Pelayanan Prima Dan Iklim Investasi Yang Kondusif Untuk Mendorong Pertumbuhan Ekonomi Daerah Yang Maju Mandiri Dan Berdaya Saing" . Dalam upaya meningkatkan iklim investasi yang kondusif untuk mendorong pertumbuhan ekonomi daerah dengan moto Quick \& Excellent Service, maka dengan Adanya pelayanan terpadu satu pintu diharapkan dapat menarik minat para pemilik modal untuk berinvestasi di kota Kendari dengan Semakin cepat, mudah dan ramah memberikan pelayanan pengurusan izin untuk meningkatkan Pendapatan Asli Daerah (PAD) Kota Kendari .

Dalam Pelaksanaan Pelayanan Prima, penerima layanan/pelanggan merupakan faktor terpenting dalam unsur Pelayanan Prima. Kepuasan penerima layanan menjadi alat evaluasi 
bagi penyelenggara pelayanan publik. Fenomena saat ini Penerapan strategi pelayanan prima terkendala oleh minimnya kualitas SDM (Sumber Daya Manusia), tidak hanya dari sisi kemampuan dan kompetensi yang tidak memadai, tetapi juga sikap dan perilaku SDM sebagai di lini terdepan dalam permberi layanan (Dwiyanto, 2005). Wujud dimensi perilaku birokrasi sebagai sikap dan tindakan dalam memberikan pelayanan meliputi tiga dimensi yaitu kepedulian, kedisiplinan dan tanggung jawab kerja (Miftha Thoha, 2005). Perilaku itu sendiri merupakan sesuatu yang sangat kompleks dan merupakan resultan dari berbagai macam aspek internal maupun eksternal. Perilaku itu tidak akan berdiri sendiri namun dipengaruhi oleh faktor faktor yang lain.

Gambaran mengenai Perilaku Aparatur Sipil Negara dalam memberikan pelayanan publik sering menjadi sebuah perbincangan yang menarik di masyarakat sebagai penerima layanan, sering kita jumpai warga/masyarakat ketika telah berurusan dengan pihak instansi mana pun pasti hal yang dinilai lebih awal tentang perilaku pegawai dalam memberikan layanan, Perilaku Aparatur Sipil Negara merupakan tolak ukur utama tercapainya pelayanan prima, dan merupakan suatu penilaian terhadap kinerja pemerintah yang paling kasat mata. Masyarakat dapat menilai langsung kinerja pemerintah berdasarkan pelayanan yang diterimanya baik secara langsung maupun tidak langsung. Para pelayan publik baik dari jabatan struktural yang paling tertinggi sampai paling bawah bahkan sampai staff loket pelayanan pun memiliki tanggung jawab yang besar terhadap publik, dan tentu nya sikap dan perilaku mereka kepada publik/masyarakat juga merupakan penentu keberhasilan mereka kepada masyarakat sebagai konsumen pelayanan.

Berangkat dari penjelasan diatas, penulis tertarik dan akan Membahasnya kedalam penelitian dengan judul Perilaku Aparatur Sipil Negara Dalam Memberikan Pelayanan Prima (Excellent Service) Pada Dinas Penanaman Modal Dan Pelayanan Terpadu Satu Pintu Kota Kendari

Tujuan dalam penelitian ini adalah untuk mengetahui dan mendeskripsikan perilaku Aparatur Sipil Negara dalam memberikan pelayanan dan mendeskripsikan pelaksanaan pelayanan prima (Excellent Service) pada Dinas Penanaman Modal Dan Pelayanan Terpadu Satu Pintu Kota Kendari

Kerangka kerja dalam penelitian yang dilaksanakan pada Dinas Penanaman Modal Dan Pelayanan Terpadu Satu Pintu Kota Kendari ini penulis memfokuskan pada teori perilaku yang dikemukakan Notoatmodjo (2011) indikator atau dimensi-dimensi Perilaku Aparatur Sipil negara dalam memberikan pelayanan dapat dinilai dari: 1)Menerima (Receiving), 2) Merespon (Responding), 3) Menghargai(Valuing), 4. Bertanggung jawab (Responsible) terhadap pengguna layanan. Kemudian di kembangkan melalui Variabel tentang Pelayanan Prima (excellent service) memfokuskan pada teori pelayanan prima yang di kemukakan oleh Mahmudi (2005:237) dengan mengkaji 1.Prosedur Pelayanan, 2.Waktu 
Penyelesaian, 3.Biaya Pelayanan, 4.Produk Pelayanan,5.Sarana dan Prasarana 6.Kompetensi Petugas Pemberi Layanan, dan Untuk lebih jelasnya keterkaitan antar variabel dalam penelitian ini seperti yang terlihat pada gambar 1.

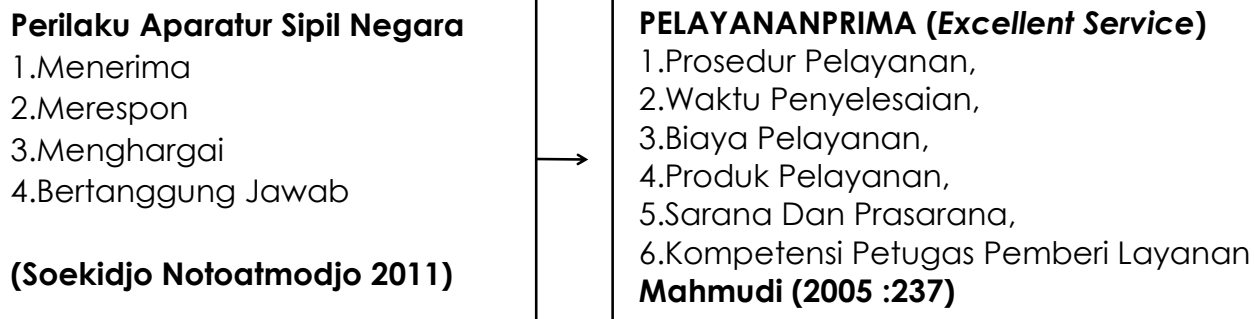

Gambar 1. Kerangka Pikir

\section{METODOLOGI}

Metode penelitian yang digunakan adalah pendekatan kualitatif yaitu "suatu prosedur penelitian yang menghasilkan data deskriptif berupa tulisan dan prilaku yang dapat diamati dari subyek itu sendiri. Sedangkan jenis penelitian yang digunakan adalah studi kasus yaitu merupakan pengujian secara rinci terhadap, suatu latar, satu subyek, atau satu peristiwa tertentu. Dalam penelitian ini studi kasus dititik beratkan pada Perilaku Aparatur Sipil Negara Dalam Memberikan Pelayanan Prima (Excellent Service) dengan Teknik analisis data yang dipergunakan dalam penelitian ini adalah teknik deskriptif menurut Miles dan Huberman (1992:16). dengan membuat gambaran yang dilakukan dengan cara (1) reduksi data atau penyederhanaan (data reduction), (2) paparan/sajian data (data display), dan (3) penarikan kesimpulan.

\section{HASIL DAN PEMBAHASAN}

Pada bagian ini, penulis menjelaskan berdasarkan indikator yang digunakan dalam kerangka pikir penelitian. Berikut dijelaskan berdasarkan temuan penelitian dan analisis indikator atau dimensi-dimensi Perilaku Aparatur Sipil negara dalam memberikan pelayanan dapat dinilai dari: 1)Menerima (Receiving), 2) Merespon (Responding), 3) Menghargai(Valuing), 4. Bertanggung jawab (Responsible) terhadap pengguna layanan. Kemudian di kembangkan melalui Variabel tentang Pelayanan Prima (excellent service) memfokuskan pada teori pelayanan prima yang di kemukakan oleh Mahmudi (2005:237) dengan mengkaji 1.Prosedur Pelayanan, 2. Waktu Penyelesaian, 3.Biaya Pelayanan, 4. Produk Pelayanan,5.Sarana dan Prasarana, 6. Kompetensi Petugas Pemberi Layanan

\section{Perilaku Aparatur Sipil Negara dalam memberikan pelayanan}

Menurut teori Lawrance Green dan kawan-kawan dalam (Notoatmodjo, 2007) menyatakan bahwa perilaku manusia dipengaruhi oleh dua faktor pokok, yaitu faktor perilaku (behaviorcauses) dan faktor diluar perilaku (non behaviour causes). Selanjutnya perilaku itu sendiri ditentukan atau terbentuk dari 3 faktor yaitu: 
1. Faktor predisposisi (predisposing factors), yang mencakup pengetahuan, sikap :

Menurut Zimbardo dan Ebbesen dalam Linggasari (2008), sikap adalah suatu predisposisi (keadaan mudah terpengaruh) terhadap seseorang, ide atau obyek yang berisi komponen-komponen cognitive, affective danbehavior (Terdapat tiga komponen sikap, sehubungan dengan faktor-faktor lingkungan kerja, sebagai berikut:

a) Afeksi (affect) yang merupakan komponen emosional atau perasaan.

b) Kognisi adalah keyakinan evaluatif seseorang. Keyakinan-keyakinan evaluatif, dimanifestasi dalam bentuk impresi atau kesan baik atau buruk yang dimiliki seseorang terhadap objek atau orang tertentu.

c) Perilaku, yaitu sebuah sikap berhubungan dengan kecenderungan seseorang untuk bertindak terhadap seseorang atau hal tertentu dengan cara tertentu (Winardi, 2004). Seperti halnya pengetahuan, perilaku terdiri dari berbagai tingkatan, yaitu:

- menerima (receiving), menerima diartikan bahwa subjek mau dan memperhatikan stimulus yang diberikan.

- Merespon (responding), memberikan jawaban apabila ditanya, mengerjakan, dan menyelesaikan tugas yang diberikan adalah suatu indikasi dari sikap.

- Menghargai (valuing), mengajak orang lain untuk mengerjakan atau mendiskusikan suatu masalah adalah suatu indikasi sikap tingkat tiga.

- Bertanggung jawab (responsible), bertanggung jawab atas segala suatu yang telah dipilihnya dengan segala risiko merupakan sikap yang memiliki tingkatan paling tinggi Notoatmodjo (2011).

2. Faktor pemungkin yang mencakup lingkungan fisik, tersedia atau tidak tersedianya fasilitas-fasilitas atau sarana-sarana keselamatan kerja, misalnya ketersedianya alat pendukung, pelatihan dan sebagainya.

3. Faktor penguat, faktor-faktor ini meliputi Undang-Undang, Peraturan-Peraturan, pengawasan dan sebagainya

Perilaku Aparatur Sipil Negara dalam memberikan pelayanan pada Dinas Penanaman Modal dan Pelayanan Terpadu Satu Pintu Kota Kendari di uraikan sebagai berikut:

1) Menerima (Receiving); adalah perilaku yang di tujukan aparatur sipil negara di dinas penanaman modal dan pelayanan terpadu satu pintu kota kendari dalam menerima dan memperhatikan masyarakat yang diberi layanan, Keramahan pegawai dalam memberikan layanan dapat disimpulkan bahwa pegawai pada Dinas Penanaman Modal Dan Pelayanan Terpadu Satu Pintu Kota Kendari sebagian pegawai sudah menunjukkan sikap keramahan terhadap masyarakat sebagai penerima layananan dengan menciptakan iklim pelayanan, membangun komunikasi dan hubungan yang baik dengan masyarakat dalam memberikan pelayanan dengan budaya $5 \mathrm{~S}$ (Senyum, Salam, Sapa, Sopan, Santun) namun tidak dapat di pungkiri bahwa masih ada pula 

pegawai yang belum menunjukan sikap yang ramah kepada masyarakat dan itu merupakan faktor secara individual pegawai.
dalam hal pegawai memberikan penjelasan dan pemahaman mengenai prosedur pelayanan sudah diterapkan dan dilaksanakan hanya saja masih di perlukan perlakuan khusus dari beberapa masyarakat yang tidak mengerti tentang penjelasan prosedur pelayanan seperti perlakuan khusus untuk masyarakat yang tidak paham teknologi untuk pelayanan yang lewat online.

\section{2) Merespon (Responding)}

Merespon adalah Perilaku dari Aparatur Sipil Negara dilihat dari kemampuan menanggapi permohonan dan layanan keluhan ,memberikan jawaban apabila ditanya, mengerjakan, dan menyelesaikan tugas yang diberikan adalah suatu indikasi dari sikap pegawai dalam memberikan pelayanan kepada masyarakat, di penelitian ini penulis memfokuskan pembahasan kedalam penilaian penilaian indikator kemampuan pegawai menanggapi permohonan \& keluhan masyarakat dan respon pegawai memberikan layanan sesuai dengan mekanisme pelayanan

Dalam hal Kemampuan Pegawai Menanggapi Permohonan \& Keluhan Masyarakat pegawai pada Dinas Penanaman Modal Dan PTSP Kota Kendari sudah memiliki pengetahuan yang baik terhadap prosedur pelayan dan pengetahuan dan kemapuan tentang teknis pelayanan yang meliputi retorika yang baik, sopan santun, dan kemampuan memecahkan masalah permohonan dan pengaduan masyarakat apa lagi di dukung dengan fasilitias ruang konsultasi dan pengaduan,pegawai yang paham, teknis di siapkan untuk menanggapi keluhan dan permohonan masyarakat. tetapi masih ada sebagaian pegawai yang belum mampu melaksanakan pelayanan yang baik, sehingga masih membutuhkan pengembangan pegawai kedepanya.

Pegawai Memberikan Layanan Sesuai Dengan Mekanisme Pelayanan responsifitas pegawai pada Dinas Penanaman Modal Dan Pelayanan Terpadu Satu Pintu Kota Kendari sudah cukup baik pegawai telah tanggap terhadap kebutuhan masyarakat dan merespon dengan baik, ramah serta sopan dalam menanggapi pertanyaan-pertanyaan apalagi ditunjang dengan adanya ruang konsultasi pengaduan,kotak saran, SPP dan SOP yang di pajang di ruang pelayanan front office sehingga masyarakat diberikan leluasa untuk menngkosultasikan permohonan dan keperluan yang diajukan. Akan tetapi responsifitas pegawai perlu untuk ditingkatkan dikarenakan dari hasil wawancara dengan masyarakat diketahui bahwa masih ada pegawai yang kurang ramah dan tidak merespon baik pertanyaan, yang diajukan masyarakat, susah untuk di hubungi yang disebabkan oleh faktor-faktor tertentu akan tetapi sebagai publik service pegawai harus senantiasa bersikap profesional untuk memberikan kenyamanan dan kepuasan bagi masyarakat dalam hal memberikan layanan. 


\section{3) Menghargai (Valuing)}

menghargai adalah Perilaku menghormati dan mengindahkan yang di tujukan Aparatur sipil Negara kepada masyarakat mengajak orang lain untuk mengerjakan atau mendiskusikan suatu masalah dalam memberikan pelayanan Kepada masyarakat, dalam penelitian ini perilaku menghargai yang di identifikasi penulis untuk dideskripsikan adalah tentang perilaku pegawai dalam mengahargai masyarakat untuk yang berkebutuhan khusus, penyandang disabilitas usia manula dan ibu hamil yang mengurus dan di beri pelayanan di dinas penanaman modal dan pelayanan terpadu satu pintu kota kendari,dan perilaku pelayanan kepada masyarakat yang normal di dimensi ini akan membahas tentang indikator perilaku mengahargai di tinjau dari Perilaku pegawai kepada masyarakat yang berkebutuhan khusus, penyandang disiablitas,ibu-ibu hamil dan usia manula dan kreatifitas pegawai memberikan pelayanan

Pegawai melayani Masyarakat Yang Berkebutuhan Khusus perilaku sudah dilayani dengan baik di dinas penanaman modal dan PTSP kota kendari,hal tersebut telah didukung dengan adanya jalur khusus untuk penyandang disabilitas,papan informasi yang bertuliskan

"Dahulukan Lansia, Disabilitas dan Ibu Hamil" hanya saja ada dibutuhkan perlakuan khusus untuk masyarkat lansia yang tidak paham teknologi untuk pelayanan sifatnya online

Kreatifitas pegawai memberikan pelayanan bahwa pegawai pada Dinas Penanaman Modal dan PTSP telah memiliki inisiatif untuk belajar ,mengahrgai kritikan masyarkat serta mengembangkan potensi diri dengan memanfaatkan perkembangan ilmu pengetahuan dan teknologi yang ada untuk menunjang kualitas pelayanan kepada masyarakat. Pegawai pada Dinas Penanaman Modal dan PTSP Kota Kendari telah mampu untuk menyampaikan inovasi untuk meningkatkan pelayanan seperti inovasi Excellent Service yang terdiri dari Three in one, One hour service, one day service yang telah diterapkan sejak tahun 2016 yang lalu, dimana dari penerapan inovasi ini lebih memudahkan masyarakt dalam mengurus izin. Sementara itu inovasi pegawai ini terus di kembangkan dimana di tahun 2019 ini akan di tingkatkan menjadi quick and excellent service.

\section{4) Bertanggung Jawab}

Tanggung jawab adalah kesadaran manusia akan tingkah laku atau perbuatan yang disengaja maupun yang tidak di sengaja. Tanggung jawab juga berarti berbuat sebagai perwujudan kesadaran akan kewajibannya.tanggung jawab yang dimaksud peneliti adalah berkaitan dengan tanggung jawab seorang pegawai Aparatur Sipil Negara terhadap pelaksanaan tugas-tugas yang di berikan dan dibebankan kepadanya Pegawai di Dinas Penanaman Modal dan PTSP Kota Kendari dalam bertanggung jawab terhadap tugas pelayanan yang diberikan sudah memenuhi apa yang menjadi di aturan 
janji pelayanan, maklumat pelayanan dan pakta integritas yang sudah ditanda tangani masing masing pegawai dan hal tersebut harus di indahkan oleh setiap pegawai ASN yang bertugas Di Dinas Penanaman Modal dan PTSP Kota Kendari . jika terjadi penyelewengan yang dilakukan maka pegawai tersebut akan diberi sangksi . namun fenomenanya masih adaditemukan pegawai yang belum bertanggung jawab terhadap tugasnya, meninggalkan secara sengaja masyarakat pengguna layanan saat melakukan transaksi pelayanan dan saat masyarakat meminta arahan beberapa pegawi sulit untuk dihubungi karna hal itu tidak luput dari pengamatan penulis ketika melakukan penelitian di instansi tersebut.

Temuan penelitian tersebut seharusnya dapat menerepakan pola perilaku sebagai manusia normal seperti yang disampaikan Notoamodjo Dalam (Yusuf.2016) Perilaku adalah semua kegiatan atau aktifitas manusia baik yang diamati langsung maupun yang tidak di amati pihak luar. Perilaku manusia pada hakikatnya adalah tindakan atau aktifitas dari manusia itu sendiri yang mempunyai bentangan luas antara lain: berjalan, berbicara, menangis, tertawa, bekerja, kuliah, membaca dan sebagainya. Perilaku manusia dapat dibedakan menjadi dua tipe, perilaku yang tidak dapat diamati langsung dan perilaku yang dapat di amati langsung . perilaku yang tidak dapat di amati secara langsung disebut juga perilaku pasif atau respons internal sedangkan perilaku yang dapat di amati secara langsung disebut perilaku aktif atau respon eksternal. perilaku pasif terjadi di dalam diri individu contohnya: berfikir dan berfantasi atau berangan-angan, perilaku aktif sifatnya terbuka dan berupa tindakan nyata contohnya : berbicara dan mengerjakan sesuatu. Supriyanto Dalam (Yusuf .2016)

Dalam ilmu Psikologi memandang perilaku manusia (human behavior) sebagai reaksi yang dapat bersifat sederhana maupun bersifat kompleks. Berbicara tentang perilaku, manusia itu unik /khusus, artinya tidak sama antar dan inter manusianya. Baik dalam hal kepandaian, bakat, sikap, minat, maupun kepribadian. Manusia berperilaku atau beraktivitas karena adanya tujuan tertentu. Adanya need atau kebutuhan diri seseorang maka akan muncul motivasi/penggerak, sehingga manusia itu berperilaku, baru tujuan tercapai dan individu mengalami kepuasan. Siklus melingkar kembali memenuhi kebutuhan berikutnya atau kebutuhan lain dan seterusnya dalam suatu proses terjadinya perilaku manusia.

\section{Pelaksanaan Pelayanan Prima (Excellent Service)}

Pelayanan prima merupakan terjemahan dari istilah "Excellent Service" yang secara harfiah berarti pelayanan yang sangat baik dan atau pelayanan yang terbaik. Disebut sangat baik atau terbaik, karena sesuai dengan standar pelayanan yang berlaku atau dimiliki oleh instansi yang memberikan pelayanan. Apabila instansi pelayanan belum memiliki standar 
pelayanan, maka pelayanan disebut sangat baik atau terbaik atau akan menjadi prima, manakala dapat atau mampu memuaskan pihak yang dilayani (pelanggan).

Untuk menjawab pertanyaan penelitian, maka temuan penelitian di uraikan berdasarkan Standar pelayanan masyarakat seperti yang dikemukakan oleh Mahmudi (2005: 237) bahwa cakupan standar pelayanan masyarakat yang harus di tetapkan secukup meliputi:

\section{1) Prosedur Pelayanan}

Pelaksanaan Pelayanan prima dapat ditinjau dari Prosedur pelayanannya, Prosedur pelayanan adalah merupakan salah satu dari standar pelayanan publik yang harus dibakukan bagi pemberi dan penerima pelayanan publik termaksud pengaduan sehingga tidak terjadi permasalahan dikemudian hari .prosedur pelayanan harus ditetapkan melalaui standar pelayanan minimal sehingga pihak penerima layanan dapat memahami mekanisme pelayanan.

Prosedur pelayanan pada Dinas Penanaman Modal Dan Pelayanan Terpadu Satu Pintu Kota Kendari dalam pelaksanaan nya sudah ditetapkan aturan baku untuk mempermudah masayarakat dalam melakukan pengurusan dan untuk masing-masing jenis pelayanan seperti pelayanan penanaman modal dan pelayanan perizinan dan non perizinan sudah dibuatkan alur diagram peta prosedur pelayananya masing-masing dan lengkap dengan syarat-syaratnya dipajang didinding-dinding ruang pelayanan ada yang berupa baliho, dan standing banner, selebaran-selebaran jenis pelayanan dan lain-lain hanya saja masih ditemukan kendala dimasyarakat sejak Dinas Penanaman Modal dan PTSP Kota Kendari ketika melakukan transisi pelayanan dari manual ke online terutama untuk pendaftaran perizinan banyak masyarakat di bingungkan dengan hal itu,sehingga perlu ada tindakan lanjutan dan perlakuan khusus untuk mengantisipasi hal tersebut.

\section{2) Waktu Penyelesaian}

Waktu penyelesaian adalah salah satu dimensi dari standar pelayanan publik yang mengarah pada rentan waktu berapa lama penyelesaian yang ditetapkan sejak saat pengajuan pemohon sampai dengan penyelesaian pelayanan termasuk dengan pengaduannya, semakin cepat waktu penyelesaian pelayananan maka akan semakin meningkatkan kepercayaan masyarakat akan pelayanan yang diberikan.

Berdasarkan data, hasil wawancara dan pengamatan yang dilakukan dengan informan tentang waktu yang dibutuhkan untuk penyelesaian pelayanan di Dinas Penanaman Modal dan Pelayanan Terpadu Satu Pintu Kota Kendari dapat disimpulkan bahwa kurun waktu penyelesaian pelayanan pada Dinas Penanaman Modal dan PTSP Kota Kendari bervariasi, jangka waktu penyelesaian pengurusannya tergantung jenis pelayanannya apa dan itu dimulai saat pengajuan pemohonan sampai dengan penyelesaian pelayanannya tergantung. Waktu paling lama penyelesaian produk pelayanannya adalah selama 30 hari (30 7 jam pelayanan) dan paling cepat hanya 1 hari 
(1 $x 7$ jam pelayanan ). Keterlambatan layanan disebabkan apabila persyaratan atau berkas yang dimasukkan pemohon tidak lengkap sehingga akan menghambat pegawai untuk memproses permohonan izin tersebut namun masih kembali ditemukan kendala terhadap model pelayanan menggunakan aplikasi perizinan OSS (Online Single Submission) kepada masyarakat yang disebabkan oleh ketidaktahuan mereka sendiri.

\section{3) Biaya Pelayanan}

Biaya pelayanan adalah salah satu bagian dari standar pelayanan publik yang menjelaskan tarif harga dari jenis/produk pelayanan. Biaya pelayanan termaksud rinciannya harus ditentukan secara konsisten dan tidakdibenarkan ada diskriminasi, sebab akan tidak menimbulkan kepercayaan penerima layanan kepada pemberi layanan. Biaya pelayanan harus jelas pada setiap jasa pelayanan yang akan diberikan kepada masyarakat, sehingga tidak menimbulkan kecemasan khususnya kepada pihak yang kurang mampu.

Temuan penelitian bahwa berdasarkan jenis pelayanannya, Dinas Penanaman Modal Dan PTSP Kota Kendari hampir semua rata-rata gratis tidak di pungut biaya hanya saja ada 1 jenis pelayanan yang memiliki tarif biaya pelayanan tersendiri yaitu pada jenis pelayanan izin tempat usaha minuman beralkohol, karna biayanya telah diatur berdasarkan Perda No 3 Tahun 2015 Retribusi Jasa Umum yakni untuk Distributor dan Subdistributor tarif biaya pelayanan sebesar Rp.20.000.000 kemudian untuk penjualan langsung minuman di tempat berupa Hotel Bintang sebesar Rp.10.000.000, di Restoran sebesar Rp.10.000.000 kemudian untuk di kafe/karaoke yang terdiri dari 1 s/d 7 room biayanya sebesar Rp.5.000.000, 8 s/d 14 room biayanya sebesar Rp.7.500.000 dan untuk 15 room keatas biayanya sebesar Rp.10.000.000, kemudian untuk untuk penjualan di Rumah bernyanyi/karaoke keluarga biayanya sebesar Rp.5.000.000, bar sebesar Rp.10.000.000 ,klub malam sebesar Rp.10.000.000 .pub Rp.10.000.000 diskotik sama-sama sebesar Rp.10.000.000. dan terakhir untuk Agen Minuman beralkohol biayanya sebesar Rp.10.000.000.

Biaya pelayanan perizinan pada Dinas Penanaman Modal dan Pelayanan Terpadu Satu Pintu Kota Kendari telah gratis /tidak dipungut biaya pelayanan dan transparan sesuai dengan aturan yang berlaku, sementara untuk beberapa pengurusan khusus seperti pengurusan Surat Izin Tempat Usaha (SITU) memang tidak dipungut biaya pelayanan (gratis) namun ada tarif retribusi pelayanan persampahan dan kebersihan yang wajib dilunasi yang ditetapkan berdasarakan Peraturan Daerah Kota Kendari No 3 Tentang Retribusi Jasa Umum dan dibayar langsung oleh masyarakat sesuai dengan nominal yang tertera pada slip pembayaran Bank terkait, tanpa adanya biaya tambahan maupun pungutan-pungutan lain yang haru dibayar oleh masyarakat. Adanya kepastian dan transparansi biaya pelayanan akan meningkatkan kepercayaan masyarakat terhadap kinerja aparatur sipil Negara yang bekerja/bertugas di Dinas Penanaman Modal Dan Pelayanan Terpadu Satu Pintu Kota 
Kendari tetapi ditemukan juga sebagian masyarakat beranggapan biaya tarif retribusi sampah tergolong mahal.

\section{4) Produk Pelayanan}

Produk pelayanan adalah merupakan bagian dari standar pelayanan publik dimana hasil pelayanan pengguna layanan akan diterima sesuai dengan ketentuan yang telah di tetapkan. Produk pelayanan harus di pahami secara baik dan harus disampaikan/disosialisasikan kepada masyarakat

Produk layanan perizinan Dinas Penanaman Modal Dan PTSP Kota Kendari sudah di adalah website www.PTSP.Kendarikota.go.id. mencetak selebaran-selebaran, standing banner agar setiap tamu yang datang dapat melihat produk-produk pelayanan perizinan, baliho yang ditempel di depan kantor supaya masyarakat tahu. kedepan akan di kembangkan dalam bentuk sosialisasi untuk tingkat kelurahan bahkan door to door ke masyarakat .produk pelayanan perizinan sangat banyak karna banyak jenis izin yang di terbitkan dan untuk produk terbaru Dinas Penanaman Modal Dan PTSP Kota Kendari baru di limpahkan wewenang untuk mengurusi penerbitan IMB (Izin Mendirikan Bangunan) dan kendalanya dalam pengurusan IMB karena baru di limpahkan wewenangnya awal Tahun 2019 dan sementara dibuatkan SOP (standar operasional prosedur) nya kemudian masih di temukan kendala masih kurangnya sumber daya manusia khususnya tenaga teknis untuk pengurusan IMB.

\section{5) Sarana Prasarana}

Selanjutnya Pelaksanaan Pelayanan prima juga dapat ditinjau dari dimensi sarana dan prasarana.sarana dan prasarana merupakan bagian salah satu standar dalam pelayanan publik yang sangat penting keberadaanya, penyediaan sarana dan prasarana pelayanan yang memadai oleh penyelenggara pelayanan publik akan sangat menunjang keberhasilan penyelenggara pelayanan.

Kondisi sarana dan prasara di Dinas Penanaman Modal Dan PTSP Kota Kendari sudah cukup memadai dan itu dapat dinilai dari ketersediaan kebutuhan pegawai untuk melayani pemohon yang sudah terpenuhi walaupun sering terdapat kendala pada jaringan untuk proses kelancaraan pemohon, pekerjaan yang cepat terselesaikan dan menciptakan kondisi keamanan dan kenyamanan bagi para pengguna layanan.

\section{6) Kompetensi Petugas Pemberi Layanan}

Kompetensi petugas dalam memberikan pelayanan pada Dinas Penanaman Modal Dan PTSP Kota Kendari sudah baik karna telah diatur dalam SPP dan SOP dan didukung dengan adanya pelatihan-pelatihan khusus untuk service excellent kepada petugas pemberi layanan Front Office dan Back Office. Masih ditemukan pegawai ketika ditanya tapi jawabanya berbeda semua, dan petugasnya ditemukan main pergi-pergi saja apalagi 
berhubungan dengan aplikasi perizinan OSS (Online Singgel Submision) pegawainya memandu dengan baik.sehingga perlu ada tindak lanjut dalam menyikapi hal tersebut.

Hasil dan pembahasan sesuai data yang ditemukan dalam penelitian, harapannya adalah pelayanan prima yang dimaksudkan untuk melayani masyarakat dengan sebaikbaiknya, sehingga dapat memberikan kepuasan. Pelayanan prima (excellent service) dapat diartikan sebagai suatu pelayanan yang terbaik dalam memenuhi harapan dan kebutuhan masyarakat.Pelayanan prima pada sektor publik merupakan suatu pelayanan yang memenuhi standar kualitas. Pelayanan yang memenuhi standar kualitas adalah suatu pelayanan yang sesuai dengan harapan dan kepuasan pelanggan/masyarakat. Sesungguhnya untuk dapat melaksanakan pelayanan prima Dinas Penanaman Modal Dan PTSP Kota Kendari setidaknya memenuhi bentuk layanan seperti yang sampaikan menurut Nina Rahmayanty (2010: 17) pelayanan prima adalah :

a. Pelayanan yang sangat baik dan melampavi harapan pelanggan.

b. Pelayanan yang memiliki ciri khas kualitas (quality nice).

C. Pelayanan dengan standar kualitas yang tinggi dan selalu mengikuti perkembangan kebutuhan pelanggan setiap saat, secara konsisten dan akurat (handal).

d. Pelayanan yang memenuhi kebutuhan praktis (practical needs) dan kebutuhan emosional (emotional needs) pelanggan.

Kemudian dipertegas dalam ilmu bisnis definisi mengenai pelayanan prima yang seringkali diungkapkan oleh para pelaku bisnis terdapat dalam buku pelayanan prima (Barata 2003; 27) :

a. Layanan prima adalah membuat pelanggan merasa penting

b. Layanan prima adalah melayani pelanggan dengan ramah, tepat, dan cepat

c. Layanan prima adalah pelayanan dengan mengutamakan kepuasan pelanggan

d. Layanan prima adalah pelayanan optimal yang menghasilkan kepuasan pelanggan.

e. Layanan prima adalah menempatkan pelanggan sebagai mitra

f. Layanan prima adalah keperdulian kepada pelanggan untuk memberikan rasa puas

g. Layanan prima adalah upaya layanan terpadu untuk kepuasan pelanggan

\section{KESIMPULAN}

Berdasarkan hasil analisis dalam penelitian ini, maka dapat disimpulkan bahwa:

1. Perilaku Aparatur Sipil Negara dalam memberikan pelayanan Prima Di Dinas Penanaman Modal dan Pelayanan Terpadu Satu Pintu Kota Kendari di tinjau dari dimensi menerima, merespon, menghargai dan bertanggung jawab dalam memberikan pelayanan terhadap pengguna layanan (masyarakat) sudah berjalan dengan cukup baik. 
2. Pelaksanaan pelayanan prima di Dinas Penanaman Modal dan Pelayanan Terpadu Satu Pintu Kota Kendari di tinjau dari Instrumen dimensi standar pelayanan publik yang meliputi: prosedur pelayanan ,biaya pelayanan, waktu penyelesaian,produk pelayanan,sarana prasana, dan kompetensi petugas pemberi layanan secara keseluruhan sudah baik, dalam artian bahwa Dinas Penanaman Modal Dan Pelayanan Terpadu Satu Pintu Kota Kendari dalam memberikan pelayanan prima kepada masyarakat sebagai pengguna layanan telah bekerja sesuai Standard Pelayanan Publik (SPP) dan SOP (Standar Operasional Prosedur) yang telah di bakukan dan telah berlaku untuk diterapkan tahun 2018.

\section{DAFTAR PUSTAKA}

Anoraga, Pandji dan Sri Suyati.1995. Perilaku Organisasi. Cetakan Pertama. PT. Dunia Pustaka Jaya.

Barata, Atep,2003 .Dasar-Dasar Pelayanan Prima .Jakarta.Pt.Elex Media Komputindo

Dwiyanto, Agus.2005.Mewujudkan Good Government Melalui Pelayanan Publik Yogyakarta : Gajah Mada University Press

Fremont E Kast,. \& Rosenzweig. James E. 2002. Organization and Management: A systems Approach. McGraw-Hill. Inc. New York.

Fremon E. Kastdan James E. Rosenzweig.1995., Organisasi Dan Manajemen, Jakarta: Bumi. Aksara

Islamy, M. Irfan. 2000. Prinsip-prinsip Perumusan Kebijakan Negara. Jakarta. Sinar Grafika

J Lexy. Moleong 2006. Metodologi Penelitian Kualitatif. Bandung: PT. Remaja.

Josina Judiari, , 2010, Psikologi Konsumen, Buku Ajar

Khairul, Maddy, 2009, Hakikat dan Pengertian Pelayanan Prima, Jakarta ; Chama Digit

Linggasari.2008, Faktor-Faktor Yang Mempengaruhi Perilaku.FKMUL

Mahmudi (2005), Manajemen Kinerja Sektor Publik, Yogyakarta: UPP AMP YKPN

Majid. Abdul 2011. Perencanaan Pembelajaran Mengembangkan Standar. Kompetensi Guru. Bandung: PT Remaja Rosdakarya.

Miles, B. Mathew dan Michael Huberman. 1992. Analisis Data Kualitatif Buku Sumber Tentang Metode-Metode Baru. Jakarta: UIP.

Notoatmodjo,Soekidjo 2003, Pengembangan Sumber Daya Manusia, Jakarta: PT. Rineka Cipta.

2007. Promosi Kesehatan dan IImu Perilaku. Jakarta : Rineka. Cipta.

2011 Promosi Kesehatan dan IImu Perilaku. Jakarta: PT Rineka Cipta.

Pratomo \& Shaff, Akhsin. 2000. Pelayanan Prima. Bandung: Angkasa Bandung 
Open Access at: http://ojs.uho.ac.id/index.php/PUBLICUHO/index

Pendit I.N.R.. 2004.Table Manner Dinning Etiquette dan Etiket Dalam Jamuan. Penerbit: Graha IImu

Rakhmat. Jalaluddin 2001. Psikologi Komunikasi Edisi Revisi.Bandung: PT Remaja.

Rahmayanty, Nina. 2010. Manajemen Pelayanan Prima. Yogyakarta: Graha llmu 2013. Manajemen Pelayanan Prima, Graha llmu, Yogyakarta,

Sinambela, Dr. Lijan Poltak. 2007. Reformasi Pelayanan Publik (Teori, kebijakan dan implementasi). Jakarta: Bumi Aksara

Sutedi Adrian, 2011, Hukum Perizinan Dalam Sektor Pelayanan Publik, Sinar. Grafika: Jakarta.

Suwithi, Ni Wayan, 1999, Pelayanan Prima (Costumer Care). Makalah Penataran Guru Akomodasi Perhotelan Pada Pusat Pengembangan Penataran Guru Kejuruan; Jakarta

Thoha Miftah.2005 Perilaku Organisasi: Konsep Dasar Dan Aplikasinya Jakarta : Raja Grafindo Persada (2007). Kepemimpinan Dalam Manajemen. Jakarta: PT. Raja. Grafindo

Walgito Bimo,. 2003. Pengantar Psikologi Umum, Yogyakarta.

Winardi. 2004. Manajemen Perilaku Organisasi. Cetakan kedua. Kencana Prenada.

\section{Karya Ilmiah/Jurnal :}

Andrilia Nilam Sari,2015 Dalam Skripsinya Pelaksanaan Pelayanan Prima Di Kantor Dinas Perizinan Kota Yogyakarta

Yusuf.Muhammad.2016 Dalam Disertasinya Perilaku Birokrasi Dalam Pelayanan Publik Kantor Pertanahan Kota Kendari Provinsi Sulawesi Tenggara .

Vetty Ester Lawongo,Johny Lumolos,Ismail Sumampouw.2017 dalam jurnalnya Perilaku Aparatur Sipil Negara Dalam Pelayanan Publik Di Kantor Kelurahan Moronge Selatan Kabupaten Talaud Jurnal eksekutif Jurusan IImu Pemerintahan Volome 2 No. 2 Tahun 2017 di akses 28 desember 2018

Trio Saputral dan Bunga Chintia Utami.2017 Dalam Jurnalnya Pelatihan Pelayanan Prima Tentang Perilaku Pemberi Layanan Di Kelurahan Sidomulyo Barat Kecamatan Tampan Kota Pekanbaru

\section{PerUndang-Undangan:}

Hasil Evaluasi Pelayanan Publik KEMENPAN RB 2018

INPRES No 12 Tahun 2016 Tentang Gerakan Nasional Revolusi Mental

PP No 6 Tahun 1974 Tentang Pembatasan Kegiatan Pegawai Negeri Dalam Usaha Swasta

Peraturan Menteri Pendayagunaan Aparatur Negara No 7 Tahun 2010 Tentang Pedoman Penilaian Kinerja Unit Pelayanan Publik 
Perilaku Aparatur Sipil Negara Dalam Memberikan Pelayanan Prima (Excellent Service) Pada Dinas Penanaman Modal dan Pelayanan Terpadu Satu Pintu Kota Kendari

Volume 2 Number 4 (November-January), (2019) pp.84--98

PERMENDAGRI Nomor 24 Tahun 2006 tentang Pedoman Penyelenggaraan Pelayanan Terpadu Satu Pintu

UU No 25 Tahun 2009 Tentang Pelayanan Publik

UU No 43 Tahun 1999 Tentang Pokok-Pokok Pegawaian

UU No 5 Tahun 2014 Tentang Aparatur Sipil Negara 